\title{
DIGLOSIA
}

Volume 1, Nomor 2 (Agustus 2018)

\section{PENGEMBANGAN BAHAN AJAR MATERI DEBAT DENGAN METODE ROLE PLAYING PADA SISWA KELAS X SEKOLAH MENENGAH ATAS}

\author{
Ranem $^{1, *}$, Widyatmike Gede Mulawarman ${ }^{2}$, Endang Dwi Sulistyowati ${ }^{3}$ \\ 1,* Magister Pendidikan Bahasa dan Sastra Indonesia, FKIP, Universitas Mulawarman \\ ${ }^{2,3}$ Fakultas Keguruan dan Ilmu Pendidikan, Universitas Mulawarman \\ *Pos-el korespondensi: ranemran@gmail.com
}

\begin{abstract}
The research materials development begins from the procurement process of the learning materials that are always revised with an uncertain time, contains a theme that is not necessarily in accordance with the problems that exist in the unit of education. The research is also conducted for positive character reinforcement because arguing activities often lead to selfishness in an effort to defend opinion, so debate participants often do not control the ethics of speech when arguing. Development research at class $x$ students of SMA YPM Diponegoro Tenggarong Seberang used ReD technique approve and method while the learning system is reinforced Dick. \& Carey model. In collecting techniques are done by language validation techniques experts, tests, leaner' responses, teacher's responses, and interviews. The result showed that 20 out of 25 students (80\%) completed the assessment of knowledge. Based on the observation of all teams capable of performing their duties well. The use of this method also makes the students able to achieve learning goals up to $96 \%$. Based on the result of discussions with various parties, the role playing method is generally feasible to be used in the learning process and able to strengthen the character of leaners.
\end{abstract}

Keywords: development of teaching materials, debate materials, role playing method

\begin{abstract}
ABSTRAK
Penelitian pengembangan bahan ajar berawal dari proses pengadaan bahan ajar yang selalu mengalami revisi dengan waktu yang tidak menentu dan memuat tema yang belum tentu sesuai dengan permasalahan yang ada di satuan pendidikan. Penelitian juga dilakukan untuk penguatan karakter positif karena kegiatan berdebat sering menimbulkan sifat egois dalam upaya mempertahankan pendapat, sehingga peserta debat sering tidak mengontrol etika berbicara ketika berdebat. Penelitian pengembangan yang dilaksanakan pada siswa kelas X SMA YPM Diponegoro Tenggarong Seberang, menggunakan metode R\&D, sedangkan sistem pembelajarannya diperkuat model Dick \& Carey. Teknik pengumpulan data dilakukan dengan teknik validasi ahli, angket, tes, respons peserta didik, respons pendidik, dan wawancara. Hasil penelitian menunjukkan bahwa 20 dari 25 siswa $(80 \%)$ tuntas pada penilaian pengetahuan. Pada penilaian sikap positif sudah mulai tampak dari pertemuan awal. Penggunaan metode role playing juga menjadikan peserta didik mampu mencapai tujuan pembelajaran hingga 96\%. Berdasarkan hasil diskusi dengan validator dan pengamat, pengembangan bahan ajar materi debat dengan metode role playing secara umum "layak" digunakan dalam proses pembelajaran dan efektif memperkuat karakter peserta didik.
\end{abstract}

Kata kunci: pengembangan bahan ajar, materi debat, metode role playing 


\section{DIGLOSIA}

Volume 1, Nomor 2 (Agustus 2018)

ISSN 2615-725X (Print)

Halaman 65-74

eISSN 2615-8655 (Online)

\section{A. PENDAHULUAN}

Perkembangan zaman menuntut penyesuaian kurikulum pendidikan yang berorientasi kepada perkembangan zaman. Oleh karena itu perubahan demi perubahan, revisi demi revisi kurikulum pendidikan selalu dilakukan guna memenuhi tuntutan tujuan pembelajaran yang berorientasi pada hasil dari sebuah proses pendidikan.

Sanjaya (2009:5) mengemukakan bahwa perkembangan ilmu pengetahuan dan teknologi yang sangat cepat membawa dampak terhadap berbagai aspek kehidupan termasuk terjadinya pergeseran fungsi sekolah sebagai suatu institusi pendidikan. Selanjutnya dikatakan bahwa sekolah tidak saja dituntut untuk dapat mengembangkan minat dan bakat, membentuk moral dan kepribadian, bahkan dituntut anak didik agar dapat menguasai berbagai macam keterampilan yang dibutuhkan untuk memenuhi dunia pekerjaan.

Hal ini sesuai dengan uraian materi Pelatihan Implementasi Kurikulum 2013 bagian Rasionalisasi Pengembangan Kurikulum 2013 (2013:90-92) yang menyatakan bahwa kurikulum 2013 dikembangkan berdasarkan faktor-faktor seperti (1) tantangan internal. (2) tantangan eksternal. (3) penyempurnaan pola pikir. (4) Penguatan tata kelola kurikulum. (5) penguatan materi. (6) karakteristik kurikulum 2013.

Zais (dalam Ansyar 2015:154) mengemukakan bahwa kurikulum dianggap baik kalau ia menghasilkan modal personality (tipe kepribadian ideal) menurut norma-norma dan tingkah laku budaya yang universal; sebaliknya kurikulum dianggap kurang baik, jika kurikulum itu belum menghasilkan tipe kebudayaan ideal yang berlaku. Dalam proses pembelajaran, peserta didik tidak hanya dituntut menguasai sejumlah pengetahuan, tetapi juga sejumlah keterampilan dan sikap.
Penilaian sikap secara umum dilakukan dengan pengamatan atau observasi.

Dalam pelajaran Bahasa Indonesia terdapat materi debat. Materi ini menuntut peserta didik terampil berbicara dalam posisi setuju atau tidak setuju dengan tema yang telah ditentukan dalam menanggapi sebuah permasalahan. Keterampilan berbicara dalam kegiatan debat ini, sering memunculkan rasa egois peserta didik dalam rangka mempertahankan pendapatnya, sehingga nilai-nilai kesopanan dan saling menghargai dalam berbicara sering diabaikan.

SMA YPM Diponegoro adalah salah satu satuan pendidikan yang mulai menerapkan kurikulum 2013. Keberadaan kurikulum ini menyebabkan satuan pendidikan ini harus menerapkan pembelajaran dengan menitikberatkan pendidikan karakter yang tertuang dalam KI 1 dan KI 2.

Rumusan masalah dalam penelitian ini adalah "Bagaimana perencanaan, pengembangan bahan ajar, dan efektivitas pembelajaran materi debat dengan metode Role Playing pada siswa kelas X Sekolah Menengah Atas?

Tujuan penelitian adalah untuk mengetahui perencanaan, pengembangan bahan ajar, dan efektivitas pembelajaran materi debat dengan metode role playing pada peserta didik kelas X Sekolah Menengah Atas.

Produk yang dihasilkan dalam penelitian pengembangan ini berupa paduan pelaksanaan pembelajaran materi debat dengan metode role playing beserta bahan ajar materi debat pada siswa kelas X SMA yang buku untuk peserta didik dan buku untuk pendidik. Bahan ajar sesuai dengan kelayakan setelah dievaluasi dan ditanggapi oleh ahli materi sekaligus ahli desain.

Manfaat pengembangan materi keterampilan debat dengan metode role playing adalah sebagai saran atau rekomendasi untuk subjek penelitian baik 
lembaga atau kelompok individu di lokasi penelitian karena keterbatasan metode pembelajaran yang selama ini digunakan. Kegunaan teoretis atau akademik berupa hasil pengujian terhadap teori yang digunakan yang bisa meningkatkan penguatan karakter peserta didik di sekolah.

\section{B. LANDASAN TEORI}

1. Hakikat Pengembangan Pembelajaran

Pengembangan Pembelajaran diawali dengan pengembangan kurikulum. Pengembangan pembelajaran adalah serangkaian proses yang dilakukan untuk menghasilkan satu sistem pembelajaran baru yang meliputi perencanaan, evaluasi, uji coba, umpan balik, dan hasil yang tersusun secara sistematis.

Beberapa kompetensi dasar mata pelajaran Bahasa Indonesia dapat dikembangkan dan dilaksanakan dalam kegiatan pembelajaran dengan pengembangan bahan ajar. Salah satu materi dalam pelajaran Bahasa Indonesia yang bahan ajarnya dapat dikembangkan adalah materi debat. Pengembangan bahan ajar materi debat dengan metode role playing merupakan salah satu pengembangan untuk menguatkan karakter peserta didik. Materi debat terdiri dari materi pengetahuan (KD 3.12) dan materi keterampilan (KD 4.12), merupakan bagian dari pengetahuan dan keterampilan berbahasa, yaitu keterampilan berbicara.

\section{Metode Role Playing}

Metode role playing disebut juga dengan model role playing. Menurut Jill Hadfield yang dikutip Basri Syamsu (dalam Fatrikah, 2016:06) metode pembelajaran role playing merupakan salah satu permainan gerak yang di dalamnya terdapat aturan, tujuan dan sekaligus melibatkan unsur bahagia. Menurut Zuhaerini (dalam Hamzah, 2011:220) mengemukakan metode role playing digunakan apabila pelajaran dimaksudkan untuk menerangkan suatu peristiwa yang di dalamnya menyangkut orang banyak dan berdasarkan dedaktik lebih baik didramatisasikan daripada diceritakan, karena akan lebih jelas dan dapat dihayati oleh anak.

Hamzah (2011:221) mengemukakan bahwa ada empat asumsi yang mendasari penggunaan metode role playing dan sejajar dengan metode-metode lain. Keempat asumsi tersebut antara lain:

(a) secara implisit bermain peran mendukung suatu situasi belajar berdasarkan pengalaman dengan menekankan dimensi "di sini dan kini” sebagai isi pembelajaran;

(b) bermain peran memberi kemungkinan kepada para peserta didik untuk mengungkapkan perasaan-perasaannya yang tidak dapat mereka kenali tanpa bercermin kepada orang lain;

(c) metode ini mengasumsikan bahwa emosi dan ide-ide dapat diangkat ke taraf kesadaran untuk kemudian ditingkatkan melalui proses kelompok; dan

(d) metode mengajar ini mengasumsikan bahwa proses-proses psikologis yang tersembunyi berupa sikap-sikap, nilainilai, perasaan-perasaan, dan sistem keyakinan dapat diangkat ke taraf kesadaran melalui kombinasi pemerannya secara spontan dan analisisnya.

Bermain peran menurut Hamzah (2011:221) dilakukan dengan beberapa tahap, yaitu: (a) tahap memotivasi kelompok; (b) memilih pemeran; (c) menyiapkan pengamat; (d) menyiapkan tahap-tahap permainan peran; (e) pemeranan; (f) diskusi dan evaluasi, pemeranan ulang, diskusi dan evaluasi kedua; dan (g) membagi pengalaman dan menarik generalisasi.

Sementara beberapa peneliti mengemukakan langkah-langkah pembelajarannya dengan metode role 
playing yang dimuat pada laman Idtesis.com adalah sebagai berikut. ${ }^{1}$

(a) Pertama penyusunan skenario yang akan dimainkan oleh tiap siswa dilakukan oleh guru.

(b) Sebelum kegiatan dilakukan maka guru akan memiliki beberapa siswa untuk mempelajari skenario yang akan ditampilkan, waktu yang digunakan tidaklah banyak hanya beberapa hari.

(c) Pada pembentukan kelompok bisa dilakukan acak, dan dilakukan oleh guru. Sebaiknya tiap kelompok jumlahnya 5 orang.

(d) Memberikan penjelasan tentang kompetensi yang ingin dicapai.

(e) Guru akan Memanggil para siswa yang sudah ditunjuk untuk melakonkan skenario yang sudah dipersiapkan.

(f) Skenario yang dibagikan akan dipelajari oleh tiap siswa dalam kelompok sebelum ditampilkan.

(g) Memasuki tahap akhir, Setelah selesai proses peragaan maka guru membagi lembar kerja yang bertujuan untuk penilaian atau pembahasaan atas show yang dilakukan masingmasing kelompok.

(h) Masing-masing kelompok menyampaikan hasil kesimpulannya.

(i) Guru memberikan kesimpulan secara umum.

(j) Evaluasi dilakukan untuk melihat seberapa sukses dan bila ada kekurangan akan dikaji ulang dalam pertemuan berikutnya.

(k) Penutup.

\section{Pengembangan Bahan Ajar Materi Debat dengan Metode Role Playing.}

Penelitian pengembangan bahan ajar materi debat dengan metode role playing terdiri dari materi pengetahuan dan materi keterampilan. Materi pengetahuan dikembangkan dengan tema-tema yang aktual di satuan pendidikan sedangkan materi keterampilan debat merupakan salah satu materi keterampilan berbahasa, yaitu keterampilan berbicara yang dikembangkan dengan metode role playing. Langkah pengembangan bahan ajar materi debat dengan metode role playing diawali dengan analisis materi pelajaran diikuti penggunaan metode pembelajaran dan dilanjutkan pemilihan metode untuk pengembangan bahan ajar.

\section{Proses Pengembangan}

Langkah-langkah

kegiatan pengembangan meliputi tahap persiapan dan tahap mengajar. Tahap persiapan meliputi: (a) mengidentfikasi materi yang dapat dilakukan pengembangan dengan metode role playing, yaitu materi debat; (b) menyusun rencana pembelajaran berupa silabus dan RPP untuk divalidasi kelayakannya; (c) menentukan kelompok peserta didik yang akan dijadikan subjek uji coba kelompok kecil dan kelompok besar; dan (d) menentukan teknik dan bentuk penilaian. Sedangkan tahap mengajar meliputi: (a) pendahuluan; (b) pengembangan; (c) praktik; (d) kegiatan kelompok disertai kegiatan penilaian; dan (e) kegiatan individu disertai kegiatan penilaian.

Setiap kegiatan penilaian selalu disertai instrumen penilaian. Penilaian yang dilakukan antara lain: (a) penilaian sikap yang menonjol; (b) penilaian karakter; (c) penilaian pengetahuan; (d) penilaian keterampilan; (e) penilaian diri; (f) penilaian kekompakan dalam tim; dan (g) respons pendidik/peserta didik setelah proses pembelajaran terhadap pelaksanaan pembelajaran dengan metode role playing.

\section{Debat}

Debat merupakan satu bagian dari empat keterampilan berbahasa, yaitu

1 https://idtesis.com/metode-pembelajaran-roleplaying/ 
keterampilan berbicara. Menurut Sukadi (2017:1) debat adalah saling adu argumentasi antarpribadi atau antarkelompok manusia dengan tujuan mencapai kemenangan. Menurut Hendri Guntur Tarigan (1990:120) debat adalah saling adu argumentasi antar pribadi atau antar kelompok manusia dengan tujuan mencapai kemenangan satu pihak. Ciri-ciri debat: (a) terdapat 2 sudut pandang yaitu afirmatif (pihak yang menyetujui topik) dan negatif (pihak yang tidak menyetujui topik); (b) adanya proses saling mempertahankan pendapat antara kedua belah pihak; (c) adanya adu argumentasi yang bertujuan untuk memperoleh kemenangan; (d) hasil debat diperoleh melalui voting atau keputusan juri; (e) sesi tanya jawab bersifat terbatas dan bertujuan untuk menjatuhkan pihak lawan; dan (f) adanya pihak yang berperan sebagai penengah yang biasanya dilakukan oleh moderator.

Unsur dalam kegiatan debat terdiri atas (a) mosi; (b) tim afirmasi; (c) tim oposisi; (d) tim netral, penonton/juri yang dipanggil; (e) moderator; dan ( $f$ ) penulis. Tujuan debat adalah (a) melatih keberanian mengemukakan pendapat; (b) melatih mematahkan pendapat lawan; (c) meningkatkan kemampuan merespons sesuatu masalah.

Adapun teknik pelaksanaan debat dikenal dengan tata cara debat yang baik yaitu: (a) pertanyaan atau tanggapan hendaknya dikemukakan secara profesional, tidak menghina, tidak merendahkan atau berkomentar yang menyerang pribadi tidak dapat diterima; (b) analisis kritis, sintesis, keterampilan retorika (berbicara dan intelegensia), tidak terbata-bata; (c) fokus pada posisi pihak lawan atau argument lawan. mengetahui kelemahan dan kelebihan lawan merupakan hal penting dalam strategi persiapan untuk menyangkal argumen lawan; (d) batasi argumen maksimal tiga poin; (e) gunakan logika dalam menyusun dan menyampaikan argumentasi; (f) ketahui kesalahan umum dalam berpikir seperti kesalahan logis dan gunakan secara efektif dalam menyangkal argumen lawan; (g) sajikan konten atau substansi dengan akurat dan selalu gunakan data fakta yang berhubungan dan mendukung pandangan; (h) pastikan kesahihan semua bukti eksternal yang disajikan dalam argumen; dan (i) kesimpulan dalam debat merupakan posisi kesimpulan final dan gunakan sebagai kesempatan untuk menyangkal atau untuk memojokkan lawan.

Langkah pelaksanaan debat adalah (a) pengenalan, yaitu setiap tim (baik tim afirmasi, tim oposisi, dan tim netral) memperkenalkan diri; (b) Pembicara I dari kelompok afirmasi menyampaikan argumentasi pembuka (pemahaman topik, permasalahan, analisis) secara umum yang menunjukkan bahwa mereka mendukung mosi; (c) Pembicara I dari regu oposisi menyampaikan argumentasi pembuka (pemahaman topik, permasalahan, analisis) secara umum yang menunjukkan mereka tidak setuju dengan mosi; (d) pada babak pertama ini tidak diperkenankan melakukan interupsi; (e) Pembicara II dari regu afirmasi menyampaikan dan memperkuat argumentasi yang disampaikan Pembicara I; (f) Pembicara II dari regu oposisi menyampaikan dan memperkuat argumentasi yang disampaikan Pembicara I; (g) Pembicara III dari regu afirmasi menyampaikan dan memperkuat argumentasi yang disampaikan Pembicara I dan II sekaligus menyampaikan kesimpulan terhadap mosi; (h) Pembicara III dari regu oposisi menyampaikan dan memperkuat argumentasi yang disampaikan Pembicara I dan II sekaligus menyampaikan kesimpulan terhadap mosi; (i) Tim Lawan dapat melakukan interupsi dimulai pada Pembicara II, dua menit setelah pembicara memaparkan argumentasi. Dengan maksimal dua kali interupsi \& waktu 30 detik pada satu kali interupsi. Interupsi dilarang pada 1 menit terakhir; dan (j) 
pemberian interupsi harus atas seizin moderator.

\section{Fungsi Debat dalam Pemben- tukan Karakter}

Pengembangan materi keterampilan debat dengan metode Role Playing mempunyai fungsi strategis untuk membentuk karakter peserta didik pada keterampilan berbicara, khususnya ketika mengemukakan pendapat baik yang pro maupun yang kontra.

Melalui materi keterampilan debat, peserta didik harus mampu bekerja sama dalam satu tim, memahami tim lawan, mengemukakan argumen yang logis dengan sikap dan bahasa yang santun, menjadi pemimpin dan peserta yang baik, serta harus mampu menempatkan diri sebagai sosok atau tim yang netral.

\section{Kelebihan dan Kekurangan Pengembangan Materi Debat dengan Metode Role Playing}

Kelebihan pengembangan materi debat dengan metode role playing adalah sebagai berikut.

a. Siswa bekerja sama dalam mencapai tujuan dengan menjunjung tinggi norma-norma kelompok dan individu.

b. Siswa aktif membantu dan memotivasi semangat untuk berhasil bersama.

c. Aktif berperan sebagai anggota tim untuk lebih meningkatkan keberhasilan kelompok/tim.

d. Interaksi antarsiswa seiring dengan peningkatan kemampuan mereka dalam berargumentasi.

e. Meningkatkan kecakapan individu pada keterampilan berbicara.

f. Memupuk sifat sportif dalam kompetisi

g. Meminimalisir sifat egois ketika berbeda pendapat

Sedangkan kekurangan pengembangan bahan ajar materi debat dengam metode role playing adalah sebagai berikut. a. Ketika menyampaikan pendapat, sering berebut, menyela sebelum peserta lain selesai berargumentasi.

b. Saling berargumentasi yang tak kunjung selesai bila guru tidak menengahi.

c. Siswa yang pandai akan selalu aktif tetapi yang kurang pandai akan selalu diam dan pasif.

d. Spontanitas dalam menyampaikan pendapat sering tidak diiringi etika yang baik dalam proses komunikasi karena lebih mengedepankan upaya mempertahankan pendapat yang dianggapnya benar.

e. Siswa yang berwatak keras akan sulit mengendalikan diri sehingga peran dan keberadaan guru sangat penting dalam memantau kegiatan debat.

\section{Rancangan Metode Pengem- bangan}

Langkah-langkah pengembangan bahan ajar materi debat dengan metode role playing adalah sebagai berikut.

a. Mengidentifikasi materi pelajaran Bahasa Indonesia.

b. Menganalisis materi pengetahuan debat yang dapat dikembangkan dalam bentuk mosi-mosi yang relevan.

c. Menganalisis proses pembelajaran saintifik dalam kurikulum 2013 dan metode role playing.

d. Mengidentifikasi nilai-nilai karakter yang muncul dalam proses kegiatan debat.

e. Menentukan kelompok-kelompok yang akan menjadi tim-tim dalam kegiatan debat.

f. Mengidentifikasi mosi-mosi yang dapat diangkat untuk pengembangan materi debat sehingga lebih kontekstual.

g. Mengembangkan proses pembelajaran dengan berbagai permainan atau game yang merupakan ciri khas pembelajaran yang menye- 
nangkan, sehingga pembelajaran lebih menarik dan menyenangkan.

h. Memilih materi debat untuk dijadikan praktik pengembangan bahan ajar pelajaran Bahasa Indonesia yang dituangkan dalam silabus, RPP, dan bahan ajar sebagai perangkat pembelajaran.

i. Merancang proses pembentukan kelompok, cara kerja debat, penilaian individu maupun kelompok, serta penanaman nilai-nilai karakter dalam berdebat.

j. Melaksanakan proses pembelajaran di kelas atau di luar kelas sesuai kondisi di satuan pendidikan.

k. Merevisi pengajaran untuk mengidentifikasi kesulitan pengembangan dengan memperhatikan saran dan masukan dari para ahli.

\section{METODE PENELITIAN}

1. Model Pengembangan

Metode pengembangan dalam penelitian ini adalah pengembangan bahan ajar materi debat dengan metode role playing. Metode yang digunakan dalam penelitian pengembangan adalah metode penelitian dan pengembangan (Resarch and Development) oleh Sugiyono, untuk mengembangkan bahan ajar materi debat dengan metode role playing di kelas X SMA YPM Diponegoro Tenggarong Seberang Kabupaten Kutai Kartanegara.

\section{Model Proses}

Berikut prosedur metode Dick \& Carey.

a. Mengidentifikasi tujuan pembelajaran.

b. Melakukan analisis pembelajaran.

c. Menganalisis kemampuan awal peserta didik/merumuskan tujuan pembelajaran.

d. Mengembangkan instrumen penilaian.

e. Mengembangkan strategi pembelajaran. f. Mengembangkan dan menentukan materi pembelajaran.

g. Mengembangkan dan membuat evaluasi.

h. Revisi program pembelajaran.

i. Mendesain dan membuat evaluasi sumatif.

\section{Prosedur Pengembangan}

Langkah-langkah pengembangan menggunakan Metode R\&D. Uji coba dilakukan di SMA YPM Diponegoro Tenggarong Seberang. Uji coba kelompok kecil dilakukan kepada 8 peserta didik sedangkan uji coba kelompok besar dilakukan kepada 25 peserta didik. Bahan ajar divalidasi sebelum digunakan uji coba dan divalidasi lagi setelah uji coba untuk perbaikan desain produk. Validasi dilakukan oleh Ibu Atik Sri Rahayu, M. Pd, Pendidik di SMA 10 Samarinda yang juga merupakan instruktur nasional kurikulum 2013. Selama proses pembelajaran, dilakukan pengamatan oleh rekan pendidik untuk mendapat masukan untuk kegiatan revisi produk sampai diperoleh desain produk akhir. Aspek validasi mengacu pada bahasa, kelayakan isi, dan kelayakan penyajian.

\section{HASIL DAN PEMBAHASAN}

Analisis awal menunjukkan kemandirian peserta didik merupakan potensi tersendiri untuk penerapan praktik debat dengan metode role playing dengan tam-bahan penekanan penguatan karakter dalam kerangka implementasi penerapan pendidikan karakter di sekolah.

Berdasarkan penilaian akhir ahli diperoleh hasil bahwa secara umum ahli materi menyatakan bahwa produk berkategori baik dan layak kecuali bagian tata tulis perlu direvisi, materi hendaknya ditampilkan dengan bentuk lain, dan teknik penyajian dan pendukung penyajian perlu didukung ilustrasi lain. Penilaian untuk poin-poin tersebut masih kategori "Cukup". Uji coba untuk materi pengetahuan dilakukan dengan waktu $2 \mathrm{X}$ 
pertemuan Sedangkan untuk praktik dilaksanakan $2 \mathrm{X}$ pertemuan, yaitu untuk uji coba kelompok kecil dan uji coba kelompok besar.

Hasil penilaian sikap pada kelompok kecil terdapat satu orang menonjol di karakter positif dan dua orang menonjok di karakter negatif, peserta didik yang lain dikategorikan baik. Penilaian pengetahuan dari 25 peserta didik, 20 peserta didik $(80 \%)$ tuntas dan 5 peserta didik $(20 \%)$ belum tuntas. Penilaian sikap individu, sikap religius, nasionalis, integritas, mandiri, dan gotong royong secara umum seperti terlihat dalam tabel berikut ini.

Tabel 1. Rekapitulasi Penilaian Sikap Individu

\begin{tabular}{llccc}
\hline No & Karakter/Sikap & Kriteria & Jumlah & (\%) \\
\hline 1 & Religius & BT & - & - \\
& & MT & 18 & 72 \\
& & MB & 7 & 28 \\
& & MD & - & - \\
\hline 2 & Nasionalis & BT & - & - \\
& & MT & 21 & 84 \\
& & MB & 4 & 16 \\
& & MD & - & - \\
\hline 3 & Integritas & BT & - & - \\
& & MT & 19 & 76 \\
& & MB & 6 & 24 \\
& & MD & - & - \\
\hline 4 & Mandiri & BT & 4 & 16 \\
& & MT & 19 & 72 \\
& & MB & 2 & 8 \\
& & MD & - & - \\
\hline 5 & Gotong royong & BT & - & - \\
& & MT & 15 & 60 \\
& & MB & 4 & 16 \\
& & MD & 6 & 24 \\
\hline
\end{tabular}

Pada praktik uji coba debat kelompok kecil semua peserta didik mampu merumuskan mosi dan menyusun pendapat dengan sangat baik. Kategori baik terdapat pada rumusan pendapat, tanggapan, dan penggunaan bahasa kategori baik pada tujuh orang secara variasi. Pada praktik uji coba kelompok besar, pengamatan dilakukan oleh dua orang pengamat yang merupakan rekan pendidik.

Hasil pengamatan menunjukkan bahwa semua peserta didik tuntas dengan rentang nilai antara 76-94 dengan rata-rata nilai 88. Di akhir pembelajaran, peserta didik melakukan penilaian diri dengan menggunakan Skala Likert. Hasil penilaian diri menunjukkan bahwa aspek-aspek yang berhubungan dengan materi debat dengan kategori "Sangat Memahami" 43\%, "Memahami" 96\%, "Cukup Memahami" 96\%, "Kurang Memahami" 24\%, dan "Tidak Memahami”" 1\%.

Peserta didik dan pendidik juga diberi angket untuk mengetahui respons mereka setelah mengikuti pembelajaran. Hasil respons peserta didik maupun pendidik, menyatakan bahwa secara umum dalam kategori "Baik" dengan rentang nilai 76-83 sebanyak 20 peserta didik menurut pengamat 1 dan 15 peserta didik menurut pengamat 2 .

Akhir dari kegiatan validasi menunjukkan bahwa aspek kebahasaan, kelayakan isi, dan semua dalam kategori "baik", kecuali aspek kelayakan penyajian poin pendukung materi pembelajaran kategori "cukup" dari 4 poin yang dinilai. 
Merujuk dari data keikutsertaan peserta didik selama proses pembelajaran materi debat, maka peneliti berdiskusi dengan pengamat maupun tim ahli, dapat dikemukakan bahwa produk yang berupa bahan ajar dan panduan ini dinyatakan "Baik" dan "Layak" digunakan.

Desain yang telah divalidasi oleh ahli materi sekaligus ahli desain dan dilakukan perbaikan hasilnya sebagai berikut.

(a) Secara umum materi "layak", telah ditambahkan video, dan waktu dirinci dengan detail.

(b) Tahapan saintifik tidak perlu dimasukkan secara tersurat namun tersirat. Tahapan yang muncul pada kegiatan inti di RPP langsung pada tahapan role playing kegiatan debat.

(c) Proses debat dengan metode role playing telah ditambahkan tujuan pembelajaran yaitu 1) terampil dalam memimpin debat; 2) terampil dalam menyesuaikan diri.

(d) Desain produk pengembangan untuk mewujudkan kegiatan pembelajaran yang berorientasi pada kejadian atau isu faktual.

(e) Dari perencanaan pengajaran yang mengalami perubahan berdasarkan temuan dan saran, pelaksanaan pembelajaran yang termonitor, maka penggunaan metode role playing dalam pembelajaran materi debat pada pelajaran Bahasa Indonesia kelas X SMA YPM Diponegoro Tenggarong Seberang sangat efektif untuk penanaman karakter positif dalam pembelajaran yang menyenangkan dan peningkatan keterampilan berbicara peserta didik dengan mengedepankan nilai-nilai saling menghormati dan toleransi.

(f) Produk yang dihasilkan berupa bahan ajar untuk peserta didik, bahan ajar untuk pendidik dapat dijadikan referensi pembelajaran materi yang relevan, dan buku panduan pelaksanaan pembelajaran materi debat. (g) Kelayakan isi secara umum "Baik. Merujuk dari data keikutsertaan peserta didik selama proses pembelajaran materi debat, maka model ini dinyatakan "Baik" dan "Layak" digunakan. Produk yang dihasilkan dapat dijadikan acuan untuk pengembangan materi keterampilan lainnya.

\section{E. PENUTUP}

Berdasarkan uraian hasil penelitian dan pembahasan, dapat disimpulkan bahwa kegiatan pembelajaran materi debat dapat dikembangkan dengan metode role playing yang pelaksanaannya dapat meningkatkan karakter positif peserta didik. Metode role playing sangat efektif untuk penguatan karakter dan keterampilan peserta didik dalam penguasaan materi pengetahuan debat. Nilai sikap dan keterampilan berbicara terlihat baik selama praktik debat. Produk yang dihasilkan adalah perangkat pembelajaran yang berupa bahan ajar serta panduan pelaksanaan kegiatan pembelajaran materi debat dengan metode role playing dalam pelajaran Bahasa Indonesia.

\section{DAFTAR PUSTAKA}

Ansyar, M. (2015). Kurikulum: Hakikat, Fondasi, Desain \& Pengembangan. Jakarta: Kencana.

Arikunto, S. (2010). Prosedur Penelitian Suatu Pendekatan Teknik. Jakarta: PT Rineka Cipta.

Aris, S. (2016). 68 Model Pembelajaran Inovatif dalam Kurikulum 2013. Yogyakarta: Ar-Ruzz Media.

Asyhar, R. (2012). Kreatif Mengembangkan Media Pembelajaran. Jakarta: Referensi Jakarta.

Creswell, J. W. (2015). Research Design, Pendekatan Kualitatif, Kuantitatif, dan Mixed. Yogyakarta: Pustaka Pelajar. 
Hamidi. (2007). Metode Penelitian dan Teori Komunikasi, Pendekatan Praktis Penulisan Proposal dan Laporan Penelitian. Malang: UMM Press.

Pribadi, B. A. (2009). Model Desain Sistem Pembelajaran. Jakarta: Dian Rakyat.

Rohman, M. \& Amri, S. (2013). Strategi dan Desain Pengembangan Sistem Pembelajaran. Jakarta: Prestasi Pustakarya.

Rusman. (2013). Model-Model Pembelajaran. Jakarta: PT Raja Grafindo Persada.

Salahudin, A. (2011). Filsafat Pendidikan. Bandung: CV Pustaka Setia.
Sanjaya, W. (2009). Kurikulum dan Pembelajaran. Jakarta: Kencana.

Santoso, P. (2015). Metodologi Penelitian Sastra; Paradigma, Proposal, Pelaporan, dan Penerapan. Yogyakarta: Azzagrafika.

Sapardi. (2015). Penilaian Autentik. Jakarta: PT Raja Grafindo Persada.

Sugiyono. (2013). Metode Penelitian Pendidikan, Pendidikan Kuantitatif, Kualitatif, dan R\&D. Bandung: Alfabeta. 